\title{
Identification of Karst Underground River Catchment Areas with Artificial Tracer Tests and Water Balance in Banteng Cave Springs (Karst Gombong Selatan, Central Java)
}

\author{
Muhammad Qodri Al-Ghozali ${ }^{1,2 *}$, Tjahyo Nugroho Adji ${ }^{1,2}$, Eko Haryono ${ }^{1,2}$, Ahmad Cahyadi ${ }^{1,2}$, Romza Fauzan Agniy ${ }^{1,2}$, \\ Gangsar Edi Laksono ${ }^{1}$, Alpine Prima Priambada ${ }^{1,2}$, Aulia Ika Rahmawati ${ }^{1,2}$, Danung Shodikh Mahrizkhal ${ }^{1,2}$, Andy \\ Setiawan ${ }^{1,2}$, Danang Riza Fauzi ${ }^{1,2}$, Elisabeth Supi Astuti ${ }^{1,2}$, Rahmat Dwi Putra ${ }^{1,3}$, Muslih Biladi ${ }^{3}$ \\ ${ }^{1}$ Karst Research Group, Faculty of Geography, Universitas Gadjah Mada, Yogyakarta, Indonesia \\ 2 Department of Environmental Geography, Faculty of Geography, Universitas Gadjah Mada, Yogyakarta, Indonesia \\ ${ }^{3}$ Department of Science and Geographic Information, Faculty of Geography, Universitas Gadjah Mada, Yogyakarta, Indonesia
}

\begin{abstract}
The karst hills of Gombong Selatan have abundant potential water resources, especially in locations that have underground springs and rivers. The connectivity between the subsurface passageways that is difficult to know can threaten the potential of water resources, one of which is due to pollution caused by uncontrolled human activities. Therefore, identification of catchment systems and boundaries of water catchment areas in karst aquifers is needed that can contribute to sustainable water resources management policies. This catchment identification needs to be conducted because previous studies have never explored the eastern side of this karst area. This study aims to (1) define the underground river flow connectivity (upstream-downstream) of Banteng Cave; and (2) limiting the water catchment area of Banteng Cave. The method used to determine the subsurface connectivity system was carried out through an artificial tracer test, while the catchment area was delineated using a water balance approach. The results showed that the underground river of Banteng Cave has connectivity with Lake Blembeng, as evidenced by a change in watercolour after the tracer test and breakthrough curve (BTC) analysis of the tracing test results. BTC analysis shows that the Banteng Cave passageway has one main passage and does not have a tunnel branch. The estimated area of the Banteng Cave catchment used a water balance approach, which is 141.73 hectares. The Banteng Cave karst catchment conditions are dominated by the formation of valleys and karst cones accompanied by the appearance of valleys and karst hills that are quite evenly distributed, indicating that the Banteng Cave karst catchment is included in the advanced karst development phase. Furthermore, this research contributes significantly to increase knowledge regarding the characteristics of void karst development in aquifers which in the future are very important for determining water resources management policies.
\end{abstract}

\section{Introduction}

Karst is a landscape that undergoes a more dominant process of dissolving rocks than other landforms. The complex interaction process between soluble rock, carbon dioxide in the atmosphere, and water flow makes karst landscapes distinctive [1]. The uniqueness of the karst area is characterized by the presence of eksokarst and endokarst phenomena. Eksokarst is a type of surface karst formation, whereas endokarst is a karst formation that develops below the surface [2].

Gombong Selatan has various landscape conditions as a form of the influence of the geology of its constituents and its hydrological system. One of the landscapes in Gombong Selatan is the karst landscape. The area occupies mainly in the north and a small part in the south. The Karst Gombong Selatan area has the potential for water resources in underground rivers, in watery caves and often appear as springs. It is recorded that there are 63 caves and springs scattered throughout this karst area [3].
The potential of water resources in the Gombong Selatan karst area can be threatened due to uncontrolled human activities. One of the problems that have occurred in the karst area is the presence of potassium contamination in the springs of Banteng Cave, Pakuran Village, Buayan District, which resulted in the death of many fish and livestock of residents around the cave. This incident occurred because of fishing in Blembeng Lake using potassium. It can be assumed that there is a flow relationship between Lake Blembeng and the Banteng Cave spring [4]. Therefore, studies related to water resources in these locations are critical.

One of the efforts to protect karst water resources is by knowing the characteristics of the karst aquifer. The connectivity characteristics between voids in the karst aquifer can be identified using an artificial tracer test. The data obtained can also be helpful in knowing the extent of the karst catchment area as a basis for water resources management in the karst area. Based on this background, the objectives of this study are (1) to define the connectivity of the Banteng Cave underground river flow

\footnotetext{
* Corresponding Author: m.qodri.alghozali@mail.ugm.ac.id
} 
(upstream-downstream); and (2) delineating the underground river catchment of the Banteng Cave karst.

\section{Site Description}

The karst landscape in the Gombong Selatan Hills is a tropical karst type [5], which is affected by high levels of precipitation and evaporation to form a relatively rounded closed basin [6]. The limestone formation in the area is the Kalipucang Formation. Based on the development of the existing karst morphology, this location has entered into an adult phase, which is characterized by the development of karst aquifer characteristics such as underground rivers, sinkholes and ponors, conduit passages, and sinking streams [5].

The Banteng Cave is administratively located in Pakuran Village, Buayan District, Kebumen Regency, Central Java. Banteng Cave is located at an altitude of 331 masl with absolute positions of 49M 330360 (easting) and 9148422 (northing). Banteng Cave is a horizontal cave with an underground river system. The underground river flows throughout the year (perennial) and always overflows during the rainy season. The passages that develop in the cave are relatively narrow and short, with the direction of the passage tending to the west, and can only be explored as far as 25 meters, which then has a lowroofed passage and ends at a sump [6]. This sump is the location where the water appears in the form of a narrow pool in a cave that cannot be explored anymore.

\section{Methods}

\subsection{Artificial Tracer Tests}

A tracer test is a helpful method to obtain information about subsurface flow connectivity and groundwater flow characteristics using a tracer agent [7]. The type of tracer used is a substance that is not harmful to humans and the environment, one of which is uranine.

Tracing tests in this study were initiated by installing a fluorometer type GGUN FL30 in Banteng Cave as a monitoring location, which was then poured into the Surupan Cave, which is the outlet of Blembeng Lake. The location of tracer pouring is shown in Figure 1. The distance between Surupan Caves and Banteng Caves is about 876 meters. The Banteng Cave system tracing monitoring was carried out from 23 August 2020 to 27 August 2020.
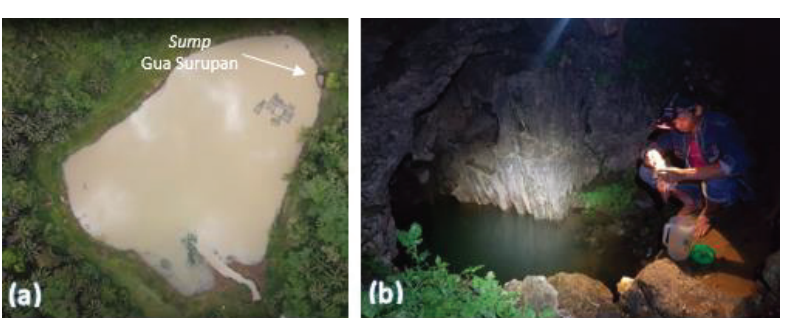

Fig. 1. (a) Blembeng Lake (b) Surupan Cave
Discharge data, target peak concentration, and horizontal distance between the injection point and the point of observation are used in calculating the quantity of tracer poured, according to the formula [8]:

$$
M=1.9 \times 10^{-5}(\mathrm{LQC})^{0,95}
$$

where:

$\mathrm{M}$ : quantity of tracer substance required $(\mathrm{kg})$;

$\mathrm{L}:$ the distance from the injection point to the observation point $(\mathrm{km})$

Q : discharge (L/s);

$\mathrm{C}$ : peak concentration target $(\mu \mathrm{g} / \mathrm{L})$

The analysis of the results of the fluorometer recording was then processed using the help of QTRACER2 software [10]. The software is able to calculate and estimate the flow properties of underground rivers quantitatively [10], which includes the average flow velocity, Reynold number and recovery value.

\subsection{Catchment Area Estimation}

Determining the catchment area's boundary using a water balance calculation is considered quite relevant and logical with the resulting catchment area [11]. The water balance concept illustrates that a hydrological system can be determined by the amount of water entering and leaving the system in a certain period [12]. Determining the catchment area using a water balance approach requires several parameters: discharge, rainfall, temperature, crop coefficient, and evapotranspiration. Discharge data is based on previous research [13], while rainfall and temperature data are obtained from en.climate-data.org between 1999-2019. The temperature data were then processed using the Blaney-Criddle method [15] to produce evapotranspiration data. The Blaney-Criddle evapotranspiration calculation is formulated as follows $[12,16]$ :

$$
P E T=\Sigma K t \times K c \times t \times p / 100
$$

where:

PET : Potential evapotranspiration;

Kt $: 0.0173 \mathrm{t}-0.314$;

$\mathrm{t} \quad$ : average monthly temperature $\left({ }^{\circ} \mathrm{F}\right)$;

Kc : crop coefficient;

$\mathrm{p} / 100$ : the monthly percentage of daylight hours in a year $(\%)$;

The value of the crop coefficient $(\mathrm{Kc})$ is adjusted to land use in the catchment area. The classification of $\mathrm{Kc}$ values is presented in Table 1 .

Table 1. Value of Kc based on land use

\begin{tabular}{lc}
\hline \multicolumn{1}{c}{ Information } & Kc \\
\hline Mixed garden & 0.80 \\
\hline Moor & 0.90 \\
\hline Settelment & 0.00 \\
\hline Irrigated rice fields & 1.15 \\
\hline
\end{tabular}




\begin{tabular}{ll}
\hline Shrubs & 0.80 \\
\hline Rainfed rice fields & 0.80 \\
\hline Grass & 0.80
\end{tabular}

Source: [16]

Water balance assumes that rainwater $(\mathrm{P})$ is the main input, then evapotranspiration (E) as a factor of water loss due to evaporation and transpiration by sunlight, and discharge (Q) of springs as the main output from the karst catchment area. This study assumes that the rainwater that enters the system directly goes to the springs to ignore the storage change factor $(\Delta s)$. Thus, the mathematical calculation of the water balance is presented in formula [2]:

$$
Q=P-E
$$

where:

$$
\begin{array}{ll}
\mathrm{Q} & \text { : spring discharge }\left(\mathrm{m}^{3} / \mathrm{sec}\right) \\
\mathrm{P} & \text { : rainfall }(\mathrm{mm} / \text { year }) ; \\
\mathrm{E} & \text { : evapotranspiration }(\mathrm{mm} / \text { year })
\end{array}
$$

Determination of the catchment area using discharge data during the measurement, which is converted into volume data using the equation:

$$
V=Q \times \text { time unit }
$$

$$
V=\frac{(Q(n)+Q(n+1)}{2}+\frac{Q(n+1)+Q(n+2)}{2}+\cdots+\frac{Q(m-1)+Q(m)}{2}
$$

Thus, the water balance mathematical calculation changes to:

$$
V=(P-E) \times A
$$

where:

$$
\begin{array}{ll}
\mathrm{V} & \text { : discharge volume }\left(\mathrm{m}^{3} / \text { year }\right) \text {; } \\
\mathrm{P} & \text { : rainfall }(\mathrm{m} / \text { year }) ; \\
\mathrm{E} & \text { : evapotranspiration }(\mathrm{m} / \text { year }) \text {; } \\
\text { A } & \text { : catchment area }\left(\mathrm{m}^{2}\right)
\end{array}
$$

\section{Result and Discussion}

\subsection{Artificial Tracer Tests}

Tracing results show that there is connectivity between Surupan Cave and Banteng Cave. This connectivity is evidenced by the change in colour to green in the underground river and the results of fluorometer recording at the Banteng Cave monitoring location. The condition of the Banteng Cave during the tracer test is shown in Figure 2. The tracer test results show that the Banteng Cave system was recharged by the mainstream originating from Blembeng Lake. Blembeng Lake is a doline with the morphology of a closed basin filled with water from underground river inlets and rainwater. The lake also has an outlet in the form of a sinking stream called Surupan Cave, the entrance to the underground river system. The direction of the sinking stream stretching tends to be northeast.

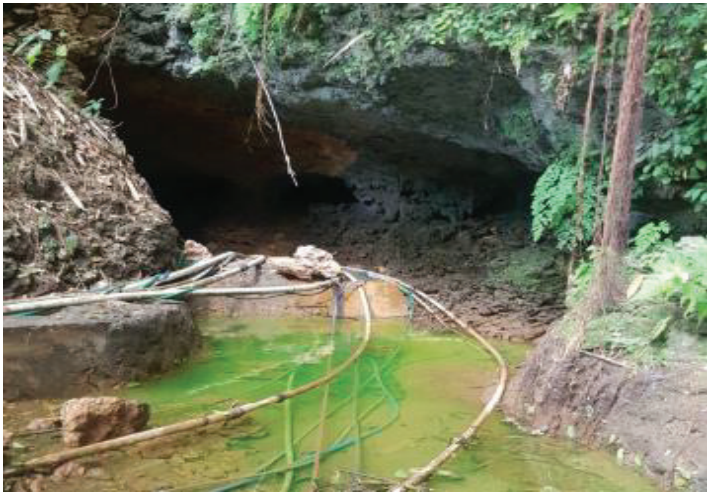

Fig. 2. The appearance of uranine in the Banteng Cave

The breakthrough curve (BTC) results of the tracing test are presented in Figure 3. The formed BTC shows one single peak, which means that there is only one single passageway system and no flow branching. The highest peak concentration was $329.57 \mu \mathrm{g} / \mathrm{l}$ with travel time to the peak concentration was 23 hours.

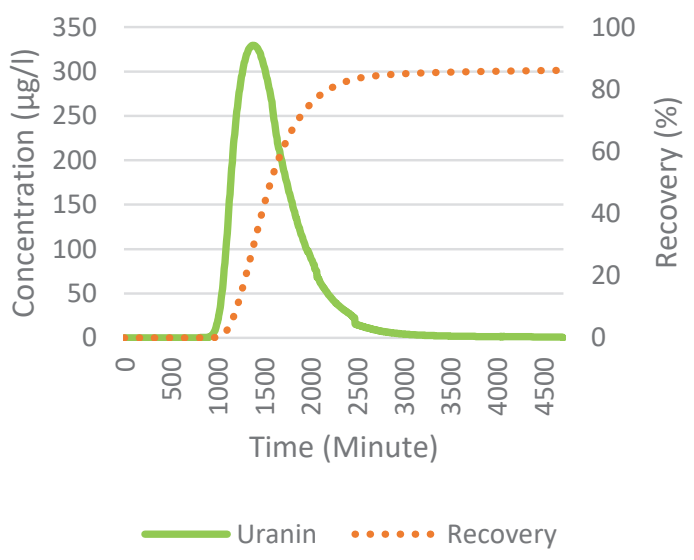

Fig. 3. BTC of the Surupan Cave-Banteng Cave

The BTC analysis in the Banteng Cave system was carried out during the dry season so that it has a slow flow rate, which is supported by a discharge calculation that shows a value of $0.06 \mathrm{l} / \mathrm{sec}$. Previous measurements by [14] stated that the discharge in Banteng Cave was 30 $1 / \mathrm{sec}$. The analysis of some of the transport parameters using QTRACER2 in the Banteng Cave system is presented in detail in Table 2 .

Table 2. BTC analysis of Banteng Cave

\begin{tabular}{lc}
\hline Observation point & $\begin{array}{c}\text { Banteng cave } \\
\text { Surupan cave } \\
\text { Unjection point }\end{array}$ \\
Tracer substance & 100.00 \\
\hline quantity $($ gram $)$ & 329.57 \\
Peak concentration $(\mu \mathrm{g} / \mathrm{l})$ & 815.00 \\
First time of detection $(\mathrm{min})$ & 876.00 \\
distance $(\mathrm{m})$ & 8978.00 \\
Reynold number estimation & 1.18 \\
Average velocity $(\mathrm{km} /$ day $)$ & 86.08 \\
recovery $(\%)$ & \\
\hline
\end{tabular}


The average velocity is a measure by which most of the mass of the substance moves in the channel [10], in this case it is also known as advection. Based on the calculation, the value of advection during the tracer test is $1.18 \mathrm{~km} /$ day. Research [17] in Linjiang, China has an advection value range of $0.8-2.3 \mathrm{~km} / \mathrm{day}$. When compared, the advection value in Banteng Cave shows relatively fast velocity and turbulent flow properties.

Turbulent flow conditions can also be detected through the Reynold number value. The turbulent flow is indicated by the Reynold number value $>4000$ [18]. Based on the results of processing the Reynold number value in the Banteng Cave, it shows a value of 8,978. These results reinforce the notion that the flow in the sub-surface system is turbulent. Turbulent flow can also be influenced by the geometry of the cave passages that are not uniform, such as the condition of the Banteng Cave passageway, which has narrow, elongated and widened passages, and there is a sump in the cave [7].

Furthermore, the recovery value shows the concentration of tracer substances that are still recorded at the monitoring location. Based on data processing, the recovery value in Banteng Cave was $86.076 \%$. In comparison, a study by [11] at Beyyayla Spring, Turkey, showed a recovery of $63.1 \%$ when the flow conditions were low. The recovery value in Banteng Cave is high; thus, it strengthens the notion that the passage system in the cave only has one main passage, and there is no flow branching in the underground river flow system [11]. The high recovery value also reflects that the karst aquifer in the system has developed [18].

\subsection{Catchment area delineation}

Temperature and rainfall data representing the research location were obtained from en.climate-data.org, recorded in 1999-2019 (Table 3). The calculation of the amount of temperature and average rainfall in 20 years is $2,484 \mathrm{~mm}$ and $25.5^{\circ} \mathrm{C}$. The data is then used to calculate potential evapotranspiration using the Blaney-Criddle method [14].

Table 3. Average temperature and rainfall at the study site,

\begin{tabular}{|c|c|c|}
\hline Month & $\begin{array}{c}\text { temperature } \\
\left({ }^{\circ} \mathrm{C}\right)\end{array}$ & rainfall $(\mathrm{mm})$ \\
\hline January & 25.6 & 359 \\
\hline February & 25.7 & 298 \\
\hline March & 25.9 & 294 \\
\hline April & 26.0 & 225 \\
\hline May & 25.8 & 128 \\
\hline June & 25.2 & 99 \\
\hline July & 24.5 & 68 \\
\hline August & 24.5 & 46 \\
\hline September & 25.2 & 83 \\
\hline October & 25.8 & 163 \\
\hline November & 25.8 & 324 \\
\hline December & 25.6 & 397 \\
\hline
\end{tabular}

Source: en.climate-data.org (2020)
The potential evapotranspiration value used is the accumulation of evapotranspiration every month. The results of the calculation of the potential evapotranspiration value in Banteng Cave are presented in Table 4. Based on these calculations, the Banteng Cave catchment has an evapotranspiration value of $1,212.16$ $\mathrm{mm} /$ year. The evapotranspiration value is then used to calculate the karst catchment area with the water balance concept. Based on calculations using water balance, the estimated area of the Banteng Cave catchment is 141.73 ha. The results of the analysis of the water balance of the Banteng Cave system are presented in Table 5. The estimated catchment area that has been determined is then delineated by on-screen digitizing to estimate the spatial catchment boundary. The digitization process takes into account topographic conditions and tracing test results. The estimation results of the Banteng Cave catchment are presented in Figure 4.

Table 4. Calculation of the evapotranspiration value

\begin{tabular}{lcccccc}
\hline Month & $\begin{array}{c}\mathbf{T} \\
\left({ }^{\circ} \mathbf{C}\right)\end{array}$ & $\mathbf{K c}$ & $\mathbf{K t}$ & $\begin{array}{c}\mathbf{P} \\
(\mathbf{\%})\end{array}$ & $\begin{array}{c}\mathbf{U} \\
(\mathbf{m m})\end{array}$ & $\begin{array}{c}\mathbf{E} \\
(\mathbf{m m} / \mathbf{y})\end{array}$ \\
\hline January & 25.6 & 0.8 & 1.04 & 8.85 & 144.98 & \\
February & 25.7 & 0.8 & 1.04 & 8.12 & 133.74 & \\
March & 25.9 & 0.8 & 1.05 & 8.68 & 144.48 & \\
April & 26.0 & 0.8 & 1.05 & 8.10 & 135.54 & \\
May & 25.8 & 0.8 & 1.04 & 8.20 & 135.79 & \\
June & 25.2 & 0.8 & 1.02 & 7.94 & 127.28 & 1212.16 \\
July & 24.5 & 0.8 & 1.00 & 8.20 & 126.63 & \\
August & 24.5 & 0.8 & 1.00 & 8.37 & 129.24 & \\
September & 25.2 & 0.8 & 1.02 & 8.10 & 129.90 & \\
October & 25.8 & 0.8 & 1.04 & 8.68 & 143.72 & \\
November & 25.8 & 0.8 & 1.04 & 8.40 & 139.09 & \\
December & 25.6 & 0.8 & 1.04 & 8.85 & 144.98 & \\
\hline
\end{tabular}

Table 5. Banteng cave catchment based on water balance

\begin{tabular}{ccccc}
\hline $\begin{array}{c}\text { Sub-surface } \\
\text { system }\end{array}$ & $\begin{array}{c}\mathbf{V} \\
\left(\mathbf{m}^{\mathbf{3}} / \mathbf{y}\right)\end{array}$ & $\begin{array}{c}\mathbf{E} \\
(\mathbf{m m} / \mathbf{y})\end{array}$ & $\begin{array}{c}\mathbf{P} \\
(\mathbf{m m} / \mathbf{y})\end{array}$ & $\begin{array}{c}\text { Area } \\
(\mathbf{h a})\end{array}$ \\
\hline Banteng Cave & 1802623.28 & 1212.16 & 2484 & 141.73 \\
\hline
\end{tabular}

Several previous studies related to determining the catchment area estimate using water balance have also been carried out in the Gunung Sewu karst area, namely, the Guntur Spring, which found an area of 30.7 ha [12] and [19] in Pindul Cave, resulting in a catchment area of around 10,000 - 20,000 ha. Knowledge of watershed boundaries is essential to determine the type of karst groundwater management that is susceptible to pollution [15].

The estimated catchment area of Banteng Cave tends to be smaller than that of the Gunung Sewu karst system. This is influenced by water limitations, leading to a narrow underground river system, which is reflected in the relatively small discharge. The area of the Banteng Cave catchment includes several villages, including Pakuran Village, Wonodadi Village, and Watukelir Village. 
The condition of the Banteng Cave catchment is dominated by karst topography with the characteristics of a conical hill and a closed depression (cockpit). The karst cone pattern is elongated with many peaks which are relatively uniform and have steep slopes. The valley pattern forms a closed basin that is elongated and relatively narrow. Based on this appearance, and also supported by the development of the karst aquifer below the surface as evidenced by the artificial tracer test in Banteng Cave, it strengthens research [7] that the Gombong Selatan karst area is in a mature karst development phase.

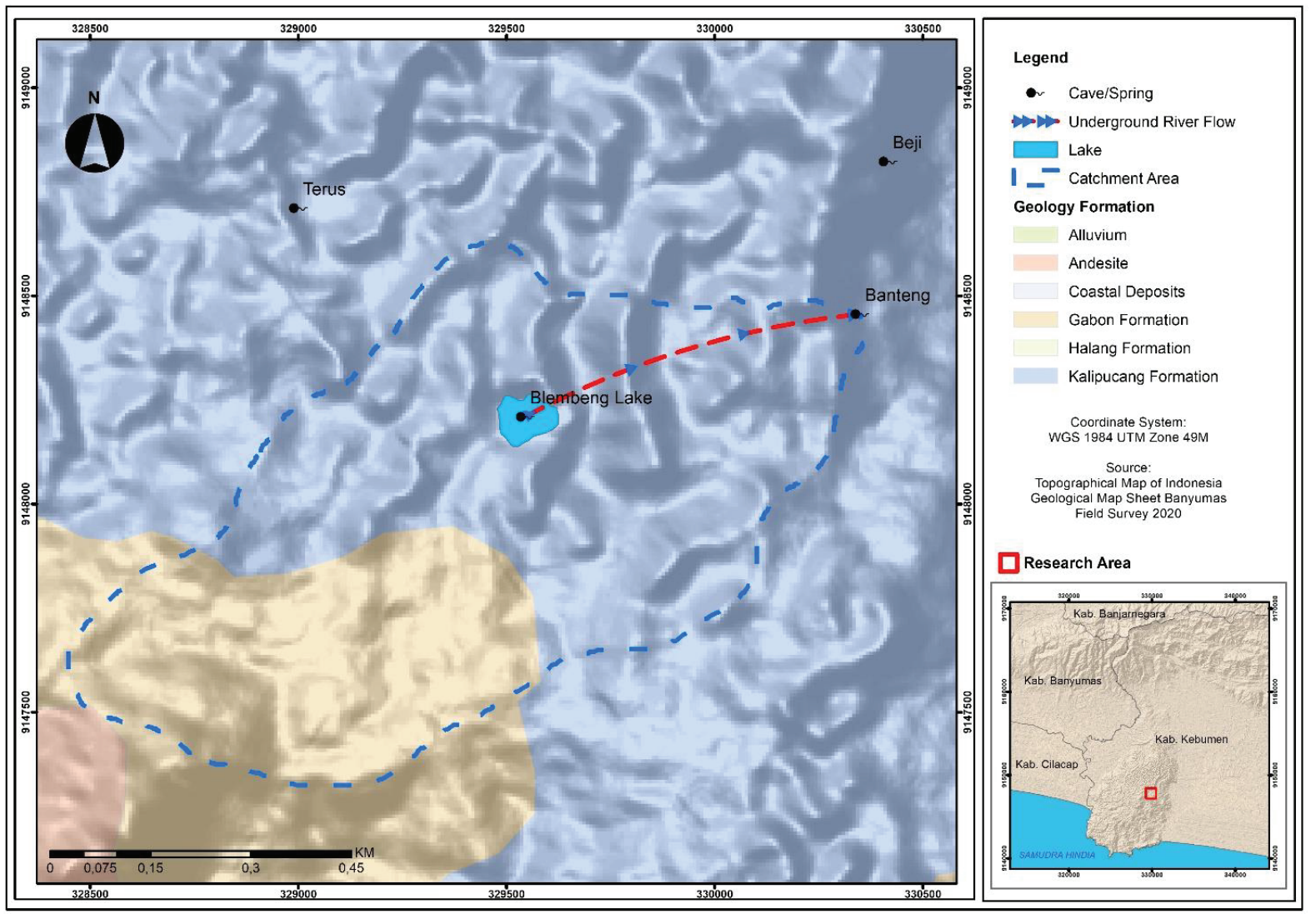

Fig. 4. Estimated catchment boundary in the Banteng Cave system

\section{Conclusion}

The connectivity between the underground river flows of Blembeng Lake-Banteng Cave has been proven through tracing tests. BTC records show that the Banteng Cave system has one main passageway and does not branch off the passageway to other springs. The quantitative analysis of the curve also indicates that the passage development has developed and is highly classified.

Determination of karst catchment estimation using water balance shows that the area of the Banteng Cave catchment is 141.73 ha. Catchment conditions dominated by karst cones and valleys, accompanied by subsurface aquifers, indicate that the Banteng Cave catchment is included in the mature karst development phase.

\section{References}

1. Sudarmadji, E. Haryono, T. N. Adji, M. Widyastuti, R. Harini, A. Cahyadi, and H. Nugraha, Seri Bunga Rampai Ekologi Lingkungan Kawasan Karst Indonesia Jilid 1 (Deepublish, Yogyakarta, 2012)
2. D. Ford and P. Williams, Karst Hydrogeology and Geomorphology (Chichester: John Wiley \& Sons, Ltd, 2007)

3. G. E. Laksono, Kajian Kerusakan Lingkungan Berbasis Indeks Ketergangguan Karst Di Kawasan Karst Karangbolong Kabupaten Kebumen, Universitas Gadjah Mada, 2019

4. Acyntyacunyata Speleogical Club, Laporan Gombong Speleology Expedition, (2014)

5. E. Haryono, Acta Carsologica., 46, 63 (2017)

6. E. Haryono and T. N. Adji, Geomorfologi Dan Hidrologi Karst (Karst Student Forum, Fakulty of Geography, Universitas Gadjah Mada, Yogyakarta, 2004)

7. N. Goldscheider, Int. J. Speleol, 37, 27, (2008)

8. S. Worthington and C. Smart, Eng. Environ. Impact Karst (2003)

9. M. Field, U.S. Environ. Prot. Agency, 1-179, (2002).

10. H. Aydin, M. Ekmekçi, and M. E. Soylu, Environ. Earth Sci. 71, 3921 (2014)

11. M. Widyastuti, I. A. Riyanto, M. Naufal, F. 
Ramadhan,, N. Rahmawati, Int. Conf. Environ. Resour. Manag. Glob. Reg., 256, (2019)

12. B. Triatmodjo, Hidrologi Terapan, (Beta Offset, Yogyakarta, 2010)

13. Ruswanto, I. Badri, and A. Anwar, Inventarisasi Geologi Lingkungan Kawasan Karst Gombong, Kabupaten Kebumen, Jawa Tengah (Dep. ESDM, Bandung, 2002)

14. R.G. Allen, W.O. Pruitt, J. Irrig. Drain. Eng, 112, 139155, (1986)

15. R. F. Agniy, Pengelolaan Sumberdaya Air Berdasarkan Sifat Akuifer Karst di Kawasan Karst Jonggrangan, 2019

16. J. Doorenbos, W. O. Pruitt,. FAO Irrig. Drain, 24, (1977)

17. J. Qi, M. Xu, , X. Cen, L, Wang, Q. Zhang, Water, 10 (2018)

18. E. Shashi Menon. Fluid Flow in Pipes. Transmission Pipeline Calculations and Simulations Manual, Gulf Professional Publishing (2015)

19. E. P. Lestari, \& M. Widyastuti, J. BUMI Indo, 6, 4 (2017). 